\title{
FINANCIAL INDICATORS AS PREDICTORS OF ILLIQUIDITY
}

\author{
Dejan JOVANOVIĆ ${ }^{1}$ \\ Mirjana TODOROVIĆ ${ }^{2}$ \\ Milka GRBIĆ ${ }^{3}$
}

\begin{abstract}
The main objective of this study is the development of the model for predicting illiquidity, i.e. identification of financial indicators on the basis of which one can predict illiquidity. The research focus is on large companies in the Republic of Serbia. Bearing in mind the results of previous research and the assumptions underlying the logistic regression, the paper relied on logistic regression for drawing conclusions. For each of the 426 companies included in the sample, based on data from financial statements, financial ratios were calculated in respect of: liquidity, activity, solvency, profitability, and effectiveness, which were used as independent variables in the study. The research results show that in the prediction of illiquidity of large companies in Serbia, from a total of 23 financial indicators included in the model, the following distinguish themselves as significant: capital turnover ratio, inventory turnover ratio, fixed-asset turnover ratio, real asset coverage ratio, net profit ratio, return on total assets, return on equity, and effectiveness of main business activity.
\end{abstract}

Keywords: prediction, illiquidity, insolvency, financial indicators, large companies, developing countries

JEL Classification: M21; G33; G01

\section{Introduction}

Processes that existentially threaten the functioning of individual companies and the economy as a whole relate to the inability to discharge liabilities on a regular basis (liquidity crisis), the inability to pay debts (solvency crisis), the inability to achieve the required level of profit (profitability crisis), and the inability to remain competitive on the market (crisis of competitiveness). All these processes are closely related and very important, with liquidity most commonly placed in the foreground. Short-term illiquidity problems arise from the inability of companies to synchronize inflows and outflows from

${ }^{1}$ University of Kragujevac, Faculty of Economics, Serbia. E-mail: djovanovic@kg.ac.rs.

2 University of Kragujevac, Faculty of Economics, Serbia. E -mail: mtodorovic@kg.ac.rs.

${ }^{3}$ University of Kragujevac, Faculty of Economics, Serbia. E -mail: mgrbic@kg.ac.rs. 
operations. These problems are usually solved by injecting liquid assets into the economy and more efficient management of cash flows. However, the problem becomes much more complicated when companies, in addition to current liabilities, cannot settle liabilities arising from the payment of interest and repayment of financial debts. In this case, in addition to illiquidity crisis, insolvency crisis occurs.

As illiquidity is a consequence, not the cause of the problem, individual and unsystematic actions in this area do not provide solutions and represent only short-term firefighting. Therefore, great efforts are invested in preventive action, primarily in the direction of the prediction of illiquidity. For these purposes, different models for the prediction of illiquidity and insolvency of companies have been developed. These models include the implementation of complex financial analyses and the use of statistical methodology. In this regard, the research subject in this paper is the prediction of illiquidity of large companies in Serbia. That is, the main objective of this paper is to create a model, i.e. identify a set of financial indicators, on the basis of which one can predict illiquidity of companies. In accordance with the presented subject and purpose of the research, the paper will test the following hypothesis: Based on the financial indicators of the company, short-term illiquidity can be predicted. To test the defined hypothesis, logistic regression will be applied. We will also use methodological procedures and techniques, inherent to the social sciences, i.e. qualitative methodology based on the study and descriptive analysis of the defined subject of the research.

Our study contributes to the relevant literature in several ways. We are faced with the illiquidity prediction, i.e. identification of financial indicators on the basis of which one can predict illiquidity. The present model allows the prediction of short-term illiquidity of the company. Identification of short-term liquidity problems can prevent a risk of entering company into crisis over a longer period of time. Also, our model attempts to include financial indicators specific to developing countries taking into consideration the specific characteristics of country. In Serbia, there is no empirical research conducted on this topic. Papers published in Serbia up to now dealt with this problem from a theoretical point of view. Their conclusions are based on the relevant literature in this field, descriptive statistics and empirical research conducted in the neighboring countries (Mramor and Valentincic, 2003; Šarlija, Penavin and Harc, 2009; Tudor, Popescu, and Andreica, 2015).

Analyzed issues are extremely relevant and important. Several factors contributed for an increased interest from the theoreticians and practitioners to have a more correct prediction of liquidity of the company. Some of these are: the liberalization of European capital markets, increased competition on national, regional and global level, increased problems of illiquidity, etc. Also, identification of corporate financial distress as early as possible is an interest to investors, creditors and other stakeholders. Analysis of liquidity and liquidity prediction in developing countries is an important interest of foreign investors. The main reasons for that are: underdeveloped economy, especially transition economies, the specific economic environment and a large number of companies with financial problems that need to be restructured. Our study does not consider the direct impact of this economic environment on the prediction illiquidity, but points to the specific nature of business in the environment of developing economies.

The authors tried to present the most up-to-date information. Study offers empirical results relevant for the theoreticians and practitioners in the areas of financial 
management and performance measurement. Our study contributes to the area of forecasting by providing a model for more accurately prediction of corporate illiquidity in short-term. For researchers, our study provides a starting point for further research in the area of financial management and prediction illiquidity. For practitioners the value of the paper is that it conceptualizes liquidity management in large companies as a learning and continuous process.

The main motivation for this research is the fact that the transition process in Serbia has not been completed for more than 25 years and that the problem of illiquidity is one of the most serious problems of the Serbian economy. At the end of 2010, one-third of inventories are funded by long-term sources while funding rules require long-term financing of all inventories (Ranković, 2011). Also, according to the Serbian Business Registry Agency at the end of 2014 even 20,424 companies were blocked for more than 90 days. The liquidity of the the economy is worse in 2014 , compared with 2007 , which is the last year the effects of the global financial crisis are not visible. The value of blocked assets from 123.5 billion in 2012, have increased by $73.1 \%$ in 2013 and additional by 13.8\% in 2014 (Malinić, 2016). In the Serbian economy, there are a large number of companies in the restructuring process, and the public companies appear as generators of illiquidity. Apart from low profitability, high level of financial indiscipline is a key reason that a large number of companies are on the verge of bankruptcy. These are the reasons that the risk of liquidity, solvency and bankruptcy transferred to healthy parts of the economy. In our study we are faced with the problem at the level of the national economy, but economic trends over the past ten years in the world show that this is a global problem. Recently, there has been growing interest in the topic of corporate financial distress prediction or even bankruptcy prediction, especially after the economic crisis that caused economic instability and generated serious financial difficulties to a high number of companies, out of which thousands eventually turned into bankruptcy (Tudor, Popescu and Andreica, 2015). The paper consists of three parts. The first part of the paper presents conceptual bases of liquidity and an overview of previous research. The second part of the paper describes the research sample and methodology, while the third section presents the research results.

\section{Theoretical Framework of the Research}

Short-term financial risks are commonly associated with (il)liquidity, due to (in)ability of companies to discharge their liabilities when due. The company's liquidity is often defined as the ability of unconditional settlement of liabilities at every moment of their maturity. Therefore, satisfying the liquidity requirements, understood as the ability of unconditional settlement of due liabilities, is defined by the power to handle the goods and services expressed in money, which is determined by the quantity, the degree of liquidity (convertibility into cash), and duration of asset turnover in a company, as well as the level and the urgency of payment obligations (Malinić, Milićević, Stefanović, 2012, 85-86).

When a company cannot pay its due liabilities, it faces illiquidity. This problem can sometimes last for a short time, or can be quickly overcome if working capital transforms into cash in the short term (e.g. debt collection, sales of assets, inventories, etc.; For more details, see: Mramor, Valentincic, 2003, 747), or by obtaining cash through 
additional borrowing. However, short-term liquidity problems may place the company at a risk of entering into crisis over a longer period of time. Seriousness of the problem is further deteriorated by the fact that illiquidity problems become apparent, i.e. perceived by external stakeholders only when they become large enough to bring the company into bankruptcy, liquidation, transfer of assets to other industries, reorganization of due liabilities, or receiving government subsidies and/or assistance (For more details, see: Altman, 1993; Altman, Marco, Varetto, 1994).

The theoretically ideal synchronization of cash flows, i.e. ensuring cash for the payment of specific due liabilities when needed, would allow the company's optimal liquidity and smooth operation without liquidity reserves. Achieving the perfect synchronization of cash flows is difficult in practice. Therefore, in terms of liquidity management of the company, it is important to consider the moment and extent of cash flow mismatch in a timely manner, as it expands the scope of available alternatives for dealing with the deficit of cash. In this context, financial theory often claims that the prediction is the key to successful cash management (Stančić, 2000, 16). With the aim of predicting, the literature has developed numerous models dealing with the prediction of illiquidity, insolvency, or other financial difficulties of the company. One of the most fruitful lines of research is the development of bankruptcy models, specifically designed for each company feature, such as size, industry, and age (Blanco-Oliver et al., 2015).

Most existing models dealing with predicting illiquidity, insolvency, or bankruptcy are based on information provided in the financial statements. Researchers include various financial indicators (ratios) in their models. Since there is no universal and generally accepted theory of illiquidity or insolvency, which defines all important variables for predicting illiquidity or insolvency, researchers generally use the results of many previous studies for the development of precise models, applicable to specific conditions (e.g. the circumstances in a country).

The first study dealing with predicting business problems using financial indicators was published in 1942 (Merwin, 1942). For many years, it was thought that the above study was, until Beaver's research, the best study on predicting business problems via financial indicators. In the 60's, researchers used statistical models to identify financial ratios that could classify companies into failure or non-failure groups. The statistical approach includes univariate and multivariate models. In his pioneering work, Beaver (1966) used a dichotomous classification test to identify financial ratios for corporate failure prediction. Beaver published the first modern scientific paper on predicting business problems via financial indicators. In his research, Beaver focused on a tenyear period (1954-1964), observing 30 financial ratios in 79 companies that were divided by industry and asset size. For each selected company, a pair was selected - a company with no problems, in the same industry, and with equal asset size. In this way, based on univariate statistical model, the first modern model for the prediction of financial distress via financial indicators was developed. The best discriminant factor was the working capital/debt ratio, which correctly identified $90 \%$ of the firms one year prior to failure. Altman (1968) was the first researcher who developed a multivariate statistical model to discriminate failure from non-failure firms. He used multivariate discriminant analysis (MDA). Like Beaver, Altman used pairs of companies, i.e. for each company in bankruptcy he looked for a company that was not in bankruptcy. He used a sample of 33 companies in bankruptcy and those that were not, making a total of 66 
companies. He divided companies by industry and size, and chose the initial group of 21 financial indicators, which he then narrowed down to five indicators. The model was extremely accurate in classifying $95 \%$ of the total sample correctly one year prior to failure (-1 year), but misclassification of failed firms increased significantly as the prediction time increased. In this way, the application of discriminant analysis created the Z-score model (Altman, 1968). Edminster (1972) conducted research with the aim to test the usefulness of financial ratio analysis for predicting small business failure. Using step-wise multiple discriminant analysis with a restriction on the simple correlation of the entering variable with the included variables, a function of independent ratio variables, which is highly accurate in classifying borrowers in the test sample, is developed. This study examined 19 common ratios and five prevailing methods of analysis. Although not all of the methods and ratios were predictors of failure, many ratios variables were found do predict failure.

Ohlson (1980) presents empirical results of a study predicting corporate failure as evidenced by the event of bankruptcy. Ohlson used the logit model to predict business failure. The nine financial ratios included in the model. Ohlson used a relatively unbiased sampling procedure because the failure/non-failure ratio in his study was more realistic. The major result of the study is that it was possible to identify four basic factors as being statistically significant in affecting the probability of failure (within one year). These are: the size of the company; a measure(s) of the financial structure; a measure(s) of performance; and a measure(s) of current liquidity. In connection with the logit model, it is interesting to point to the research conducted by Masten and Masten (2012). They compare the logit model, as a standard parametric model for predicting bankruptcy, with semi-parametric model. On a population of Slovenian listed and non-listed companies, the results show that while logit appears to be more precise in detecting bad risks, it is also true that the semi-parametric model captures better the characteristics of healthy companies. The study conducted by Altman, Giancarlo and Varetto analyzes the comparation between traditional statistical methodologies for distress classification and prediction, i.e., linear discriminant or logit analyses, with an artificial intelligence alogrithm known as neural networks. Results show, both types of techniques displayed acceptable, over $90 \%$ classification and holdout sample accuracy and the study concludes that there should be further studies and test using the two mentioned techniques (Altman, Giancarlo and Varetto, 1994).

One interesting study builds a logit model to predict financial distress among companies in the automobile supplier industry. A full range of statistical tests indicate that a reliable predictive model of financial distress correctly bifurcates more than $98 \%$ of all firms into those likely to experience financial distress in the subsequent year and those likely to remain healthy. Logit regression analysis was used to estimate the parameters of the model. Logit regression has been shown to provide flexibility and statistical power when modeling (Lo, 1986). Further, a recent test that directly compares logit regression to other modeling techniques has shown that logit regression results dominate those produced by neural networks (Yang, Platt, and Platt 1999). By contrast, other authors preferred neural networks over other model formats (Yang et al. 1999; Grančey, 2013).

Very intresting paper is focused developing an integrated decision support system and on analysing the effectiveness of the prediction models of financial distress for the case of Romania. The database consists of 14 financial ratios reflecting the company's 
Financial Indicators as Predictors of Illiquidity

profitability, solvency, asset utilization, growth ability and size for a set of 102 Romanian listed companies on the Bucharest Stock Exchange over the period 2011-2013. Out of the total sample, 50 firms were facing financial difficulties, while the rest of 52 firms were considered healthy companies, as they had not registered any losses or debts during the last three financial years starting with 2011.This paper aims to offer a practical solution to predict financial distress in Romania by focusing on developing an integrated decision support system and on analysing the effectiveness of several prediction models based on decision trees, logit and hazard models, as well as neural networks. For example logit model identified the two financial ratios as the best predictors of financial distress, namely Profit margin and Debts on Total Assets (Tudor, Popescu and Andreica, 2015). Financial ratios have been used as inputs for advanced statistical models to forecast many kinds of business event, and to identify financial and other characteristics. Financial ratios are used for all kinds of purposes. These include the assessment of the ability of a firm to pay its debts, the evaluation of business and managerial success and even the statutory regulation of a firm's performance (Barnes, 1987). Notable studies include Ingram and Copeland (1984), who used regression analysis to measure the relationship between differences in financial ratios across municipalities and the risk premiums on their bonds. For example, Rege (1984) used financial ratios to identify characteristics of takeover targets. But the main focus has been on testing (mainly multivariate) statistical models, which use financial ratios to predict business failure. These were based on the original work of Beaver (1966) and Altman (1968). Beaver (1966) says that there are many factors that prevent a measurement of the "true" predictive ability of ratios. If ratios are used to detect the financial illness of a firm, there may be many firms whose illnesses were detected before failure occurred. In these cases, the proper treatment was applied and the firm did not fail. The sample of failed firm will include those firms whose illnesses were not detectable through ratios. But he also mentioned that ratios are not the only predictors of failure.Many of before mentioned studies have indicated that analysis of selected ratios is useful for predicting failure of firms. But the main question is which ratios are the most useful? There has been considerable debate in the traditional literature as to which ratios are most useful, in particular, for assessing the likelihood of failure. The focus originated on liquidity, as an indication of both current and future cash inflows and outflows. Beaver (1966) used the concept of cash flow (net profit plus depreciation), and found that its ratio to total debt was the best classifier amongst fourteen ratios, followed by debt to total assets and the 'no credit interval' [(defensive assets - actual liabilities)/projected daily expenditure]. This ratio was also shown by Lev (1973), using balance sheet decomposition measure, to outperform other static balance sheet ratios in the prediction of failure. Also, Fadel and Parkinson (1978) found cash flow ratios good predictors of future returns on capital employed.

On the basis of these, and many other models, numerous studies have been conducted in different countries. Appiah and Abor have developed a model for predicting insolvency in respect of Great Britain, in which they used 10 variables, among which the following distinguished themselves as significant: liabilities/equity, profit/equity, net profit/sales, current assets/current liabilities. Their model has an accuracy of $97.3 \%$ (Appiah, Abor, 2009). Chung and Tam have developed a model for predicting insolvency in respect of New Zealand, They point out that the significant variables for 
predicting insolvency are: gross profit/total assets, retained profit/total assets, working capital/total assets, market value of equity/total liabilities, quick liquidity ratio, interest costs, liabilities/total assets, and return on assets (Chung, Tam, 1993).

Andreev has investigated the financial failure of companies in Spain by using logistic regression. His model identified the following indicators as significant: current liabilities/total liabilities, working capital/total assets, sales/cash, gross profit/sales, and total liabilities/equity. Logistic regression classified $95.3 \%$ healthy and $27.1 \%$ insolvent companies, and discriminant analysis identified $65.7 \%$ healthy and $68.2 \%$ insolvent companies (Andreev, 2005). Using Altman's Z-score model, Diakomihalis developed a model for predicting insolvency of Greek hotels. The variables used for predicting were: working capital/total assets, accumulated profit/total assets, pre-interest and pre-tax profit/total assets, market value of equity/book value of total liabilities, and sales/total assets. The research results showed the accuracy of prediction of bankruptcy in $83.3 \%$ of cases, three years prior to bankruptcy (15 out of 18 companies), $100 \%$ two years prior to bankruptcy ( 15 out of 15 companies), and $88.2 \%$ for one year prior to bankruptcy (15 out of 17 companies). Furthermore, the study showed that the risk of bankruptcy was higher in three- and five-star hotels, than in four- and two-star hotels (Diakomihalis, 2011).

Mramor and Valentincic created the model for the prediction of liquidity in small companies in Slovenia. In their study, they tested a number of financial indicators, and also used the data from the credit bureau. They have grouped financial ratios in seven different groups: financing ratios, liquidity ratios, turnover ratios, profitability ratios, productivity ratios, internal cost-efficiency ratios and other ratios. The conducted research showed that if the analysis included only financial indicators, without credit bureau's data, prediction of illiquid companies would be incorrect in $70 \%$ of cases, while in the case of healthy companies, it would be possible to have precise models by using financial indicators only. The percentages of accurately classified companies were very high, ranging from $87.9 \%$ to $92.1 \%$ (Mramor, Valentincic, 2003).

Šarlija, Penavin, and Harc have developed a model for predicting illiquidity of companies in Croatia. The results of their study showed that the following coefficients are important for the prediction of illiquidity: working capital/current liabilities, working capital/total assets, net working capital, total liabilities/retained profit plus depreciation, total liabilities/total assets, liabilities/equity, gross profit/interest expense, total profit/total assets, total revenue/working capital, 365/material costs/payables, 365/receivables turnover ratio, 365/inventory turnover ratio, total income/total expenses, operating income/operating expenses, financial income/financial expenses, and net profit/total revenue. Model accuracy for liquid companies was $68.16 \%$ and $74.22 \%$ for illiquid companies (Šarlija, Penavin, Hartz, 2009).

Results of previous studies show that researchers use different methodology in their models, as well as different financial ratios and other variables, significant in predicting financial difficulties. With this in mind, the aim of this paper is to develop a model for predicting illiquidity, or to identify a set of financial indicators for predicting short-term illiquidity of companies, which can lead to insolvency, but not necessarily. 


\section{Sample and Methodology}

\subsection{The Sample}

In 2012, in the Republic of Serbia, 107,363 companies performed economic activity. The most numerous were small companies, which accounted for about $95.9 \%$ of the total number of companies. There were 937 large companies, which is only $1.0 \%$ of the total number of companies. Slightly less than three-fifths of the total financial performance of the whole economy is concentrated in large companies. Furthermore, large companies generated the largest part of economic activity, so that they expressed slightly less than two-thirds of total revenue and total expenditure of the economy, still maintaining increasing trend (www.apr.gov.rs). In this study we focused on the large companies.

In organizational and methodological sense, realizations of research and data collection were based on data from 500 most successful companies, judging by the level of achieved operating income in 2012 (www.apr.gov.rs). At the request of the authors of the paper (BON 10090/2013), the specific data from the Income Statement for the year 2012 for the 500 most successful companies, based on the achieved level of operating income (AOP201), was provided by the Business Registers Agency, Register of financial statements and data on solvency of legal entities and entrepreneurs. 38 companies were excluded from the total sample of companies, for which there was no data on the number of days of illiquidity on the website of the National Bank of Serbia (www.nbs.rs - Search of debtors in enforced collection), as well as 36 companies that did not have financial statements published on the website of the Business Registers Agency, and which were, according to the Law on Accounting and Auditing (Official Gazette of RS, Nos. 46/2006, 111/2009, and 99/2011, Item 6, Classification of legal entities, Art. 7) classified as medium-sized companies in 2012. Finally, the analyzed sample included 426 large companies.

The structure of analyzed companies (Figure 1) mostly includes limited liability companies (LLC), $70.4 \%$, followed by $22.8 \%$ of joint-stock companies (JSC). Other legal forms (public, state, etc.) participated in the sample with $6.8 \%$. The above structure of the sample by legal form corresponds to the total population, where the dominant place also belongs to limited liability companies, which make even $92.5 \%$ of the total number of companies. $52.8 \%$ of the sample refers to production companies, and $47.2 \%$ to service companies.

Bearing in mind the objective of this research, it is particularly important to point to the classification of the analyzed companies into liquid and illiquid. This division was based on the data available on the website of the National Bank of Serbia, in the section Search of debtors in enforced collection (www.nbs.rs), where the illiquid companies are the ones whose account is blocked continuously for 90 days or more. 
Structure of the Analyzed Companies According to Legal Form and Activity

Figure 1

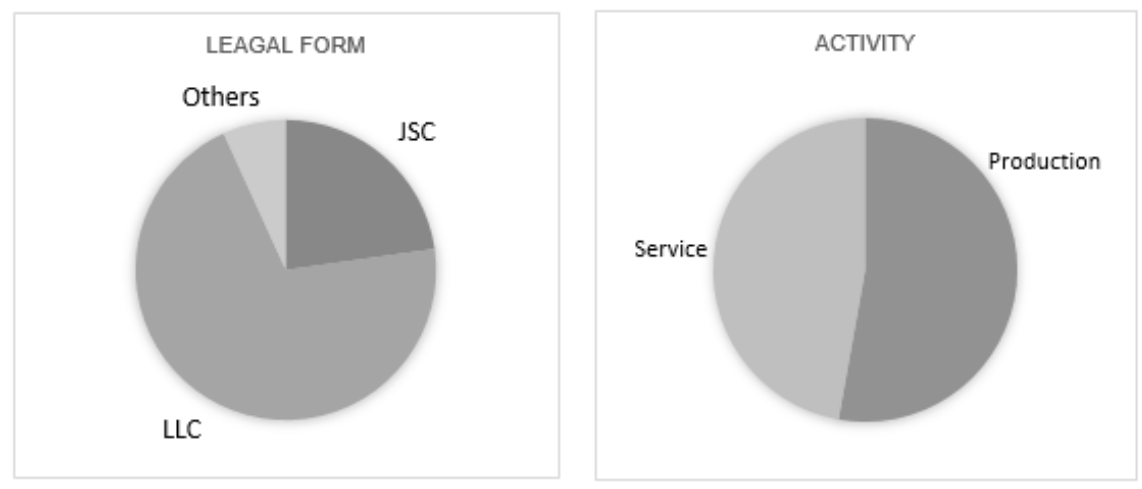

Based on the above criteria, the structure of companies in the sample is given in Table 1.

Table 1

Structure of Analyzed Companies According to Liquidity

\begin{tabular}{|l|r|r|}
\hline (il)liquid & Number & \multicolumn{1}{c|}{$\%$} \\
\hline Liquid & 401 & 94.10 \\
\hline Illiquid & 25 & 5.90 \\
\hline Total & $\mathbf{4 2 6}$ & $\mathbf{1 0 0 . 0 0}$ \\
\hline
\end{tabular}

Data presented in Table 1 indicate that only about $6 \%$ of the analyzed companies are blocked continuously for 90 days or more, i.e. that only $6 \%$ can be considered illiquid.

\subsection{Variables and Research Methodology}

For each company in the sample, based on data from financial statements (www.apr.gov.rs), the most commonly used financial indicators in domestic and foreign literature were calculated (Van Horne, 1995; Damodaran, 2001; Malinić, Milićević, Stefanović, 2012), classified into five main groups: liquidity, activity, solvency, profitability, and effectiveness. Five groups of financial indicators were used as independent variables in the study. For easier reference and understanding of the research, the appendix gives financial indicators and methods for their calculation.

Table 2 presents the arithmetic mean and standard deviation in respect of independent variables, for liquid and illiquid companies.

Table 2

Descriptive Statistics of Independent Variables

\begin{tabular}{|c|c|c|c|c|}
\hline \multirow{2}{*}{ Indicators } & \multicolumn{2}{|c|}{ Liquid } & \multicolumn{2}{c|}{ Illiquid } \\
\cline { 2 - 5 } & Mean & St.dev. & Mean & St.dev. \\
\hline CR & 1.56 & 1.69 & 1.04 & 0.80 \\
\hline QR & 1.05 & 1.39 & 0.52 & 0.34 \\
\hline Cash & 0.11 & 0.24 & 0.02 & 0.06 \\
\hline FSR & 1.13 & 2.54 & 10.58 & 32.94 \\
\hline
\end{tabular}


Financial Indicators as Predictors of Illiquidity

\begin{tabular}{|c|c|c|c|c|}
\hline \multirow{2}{*}{ Indicators } & \multicolumn{2}{|c|}{ Liquid } & \multicolumn{2}{c|}{ Illiquid } \\
\cline { 2 - 5 } & Mean & St.dev. & Mean & St.dev. \\
\hline NWC & $42,301.17$ & $6,083,509.52$ & $-103,514.44$ & $1,504,383.31$ \\
\hline ATR & 14.48 & 70.08 & 240.50 & 844.42 \\
\hline IT & 209.63 & $2,173.65$ & 6.56 & 9.02 \\
\hline DSI & 53.41 & 65.98 & 134.10 & 151.14 \\
\hline FAT & 60.70 & 478.23 & 10.19 & 30.32 \\
\hline TOAT & 1.56 & 1.66 & 1.13 & 0.79 \\
\hline NWCT & -12.20 & 327.63 & -567.79 & $2,887.99$ \\
\hline WCT & 3.53 & 3.57 & 2.01 & 1.56 \\
\hline RT & 15.06 & 51.69 & 6.29 & 4.96 \\
\hline DSR & 73.20 & 69.94 & 112.21 & 121.86 \\
\hline EFA & 1.99 & 5.21 & 0.83 & 2.15 \\
\hline RACR & 1.01 & 0.99 & 0.50 & 0.26 \\
\hline ICRNWC & 117.97 & $1,661.20$ & -0.88 & 1.94 \\
\hline WCCRNWC & -0.09 & 2.56 & -0.25 & 0.72 \\
\hline DER & 6.37 & 54.74 & 93.91 & 313.80 \\
\hline OM & 5.18 & 11.44 & -4.95 & 31.17 \\
\hline PM & 1.07 & 15.48 & -17.07 & 33.63 \\
\hline ROA & 4.12 & 13.06 & -11.95 & 21.07 \\
\hline ROE & 11.42 & 57.85 & -52.63 & 196.92 \\
\hline ETA & 1.03 & 0.12 & 0.91 & 0.16 \\
\hline EMBA & 1.07 & 0.13 & 1.00 & 0.18 \\
\hline EEA & 1.61 & 2.83 & 12.39 & 52.20 \\
\hline EFA & 5.30 & 64.82 & 0.31 & 0.38 \\
\hline & & & & \\
\hline
\end{tabular}

In each regression model, it is crucial to determine the expected value of the dependent variable for a given value of the independent variable, denoted by $E(Y \mid x)$. Since the dependent variable is with logistic regression dichotomous, in the case of conditional mean, $0 \leq E(Y \mid x) \leq 1$ applies. The change into $E(Y \mid x)$ per unit change for $x$ becomes progressively smaller as conditional mean becomes closer to 0 or 1 . The random variable $Y \mid x$ will also have the values 0 and 1 , with probabilities $1-\pi(x)$ for the value of 0 and probability $\pi(x)$ for the value 1. The expected value of $Y$ for a given $x$ is calculated as follows:

$$
\mathrm{E}(\mathrm{Y} \mid x)=0^{*}(1-\pi(x))+1^{*} \pi(x)=\pi(x)
$$

Bearing in mind the equation (1), $\pi(X)$ will be used for showing conditional mean of $Y$ for a given $x$ when using logistic distribution, i.e. on the basis of the above logistic regression, the function is as follows:

$$
\pi(x)=\frac{e^{\beta_{0}+\sum_{k} \beta_{k} x_{k}}}{1+e^{\beta_{0}+\sum_{k} \beta_{k} x_{k}}}
$$

This function is not linear with parameters $\beta_{i}, i=0 \ldots k$, but can be linearized by corresponding logit transformation. Then the following applies:

$$
1-\pi=\mathrm{P}\left(\mathrm{Y}=0 \mid \mathrm{X}_{1}=x_{1}, \mathrm{X}_{2}=x_{2}, \ldots, \mathrm{X}_{k}=x_{k}\right)=\frac{1}{1+e^{\beta_{0}+\beta_{1} x_{1}+\beta_{2} x_{2}+\ldots+\beta_{k} x_{k}}}
$$


Based on (3), it follows that

$$
\frac{\pi}{1-\pi}=e^{\beta_{0}+\beta_{1} x_{1}+\beta_{2} x_{2}+\ldots+\beta_{k} x_{k}}
$$

If both sides of the above equation are defined through natural logarithm, the following is obtained:

$$
\ln \frac{\pi}{1-\pi}=\beta_{0}+\beta_{1} x_{1}+\beta_{2} x_{2}+\ldots+\beta_{k} x_{k}
$$

This equation is called the logit and it is linear in the components $\beta_{i}, i=0 \ldots k$.

When it comes to logistic regression for estimating the regression coefficients, the maximum likelihood method is used. This method gives values for $\beta_{i}, i=0 \ldots k$ that maximize the likelihood of obtaining the registered data set, i.e. determine the likelihood (probability) of registered data for different combinations of values of regression coefficients (For more details. see: Chatterjee, Hadi, 2006; Hosmer, Lemeshow , 2000). Therefore in previous studies the most commonly used methods are logistic regression, discriminant analysis, linear regression, decision tree and neural network. We decided to use logistic regression. Our decision was based on the following: 1) logistic regression is one of the most popular methods applied in the financial industry (Crook, Edelman, Thomas, 2007) and 2) estimation and mathematical definition of the problem through logistic regression provide a very good balance between: accuracy, efficiency and interpretation of the results (Crone, Finlay, 2012).

\subsection{Fulfillment of Assumptions of Logistic Regression}

Before starting the logistic regression procedure, it is necessary to check whether the assumptions underlying logistic regression have been fulfilled. The following segment will briefly describe whether the assumptions of logistic regression in this study have been met, after which the results will be presented and the model implemented.

The sample size. As with most statistical techniques, in logistic regression, one of the issues is the number of cases in the sample compared to the number of predictors (independent variables). Tabachnick and Fidell $(2007,123)$ provide a formula for calculating the sample size, which takes into account the number of independent variables, by which $N>50+8 m$ (where $m$ is the number of independent variables). Having in mind that in our study the number of independent variables is 27 , the sample should be composed of a minimum of 266 companies. As the number of companies in the sample is 426 , we can conclude that this assumption has been fulfilled.

Multicollinearity. Before starting with the logistic regression procedure, it is necessary to check whether there is strong correlation between independent variables. Multicollinearity exists when independent variables are highly correlated $(r=0.9$ and higher). Since the correlation matrix for the listed number of variables is large, often not transparent, it is difficult to spot the possible existence of multicollinearity. Therefore, we use values Tolerance and VIF for identifying the existence of multicollinearity. Based on the determined values of Tolerance and VIF, independent variables QR, ICRNWC, $\mathrm{OM}$, and EFA have been excluded from further analysis, because they exceed the specified limit values. 


\section{Financial Indicators as Predictors of Illiquidity}

Unusual points and extreme values. Unusual points and extreme values can be identified in the residual diagram. In large samples, one can often find a large number of unusual residuals, as is the case in our study. For the purposes of determining the extent of the impact of these cases on the results of the model, the value of Cook's distance will be considered. Tabachnick and Fidell $(2007,75)$ argue that the problem may be with cases in which that value exceeds 1 . In our study, the maximum Cook's distance is 0.886 , which indicates that unusual points and extreme values will not affect the research.

\section{Research Results}

The goal of the created model is to estimate the probability of illiquidity of large companies in Serbia in the future, i.e. identifying the most important financial indicators for predicting the probability of illiquidity. The number of independent variables included in the analysis after testing multicollinearity is 23 .

After conducting a logistic regression, obtained results are classified into two parts, Block 0 and Block 1 . Block 0 includes the results of analysis without any independent variables of which the model is made of. The results are presented in Table 3.

Table 3

Classificationa,

\begin{tabular}{|c|c|c|c|c|}
\hline \multicolumn{2}{|c|}{ Observed } & \multicolumn{2}{|c|}{ Prediction of liquidity } & \multirow{2}{*}{$\%$} \\
\cline { 2 - 4 } \multirow{2}{*}{ Liquidity } & 0 Liquid & 401 & 1 Illiquid & \\
\cline { 2 - 5 } & 1 Illiquid & 25 & 0 & 100.0 \\
\hline \multicolumn{2}{|c|}{ Overall Percentage } & & 0 & 0. \\
\hline
\end{tabular}

a. Constant is included in the model. $b$. The cut value is .500

Table 3 shows that there is a total of $94.1 \%$ accurately classified cases. It can be concluded no company will have a problem with illiquidity, just because of a greater percentage of companies that are not illiquid. These results should be compared with the results of the model, which includes the predictor variables given in section Block 1. Block 1 lists the results of testing the model - set of predictor variables. The mentioned part consists of multiple tables, which are listed and explained below.

Table 4

\begin{tabular}{|c|c|c|c|c|}
\hline \multicolumn{6}{|c|}{ Omnibus Tests of Model Coefficients } \\
\hline \multirow{3}{*}{ Step 1 } & Chi-square & df & Sig. \\
\hline & Step & 99.485 & 23 & .000 \\
\cline { 2 - 5 } & Block & 99.485 & 23 & .000 \\
\cline { 2 - 5 } & Model & 99.485 & 23 & .000 \\
\hline
\end{tabular}

Table 5

Hosmer and Lemeshow Test

\begin{tabular}{|c|c|c|c|}
\hline Step & Chi-square & $\mathrm{df}$ & Sig. \\
\hline 1 & 2.040 & 8 & .980 \\
\hline
\end{tabular}


Table 4 provides the summary of indicators of performance of the model, i.e. the difference compared to the results obtained in Block 0 , where the model does not include any predictor variable. The presented test indicates how well the model predicts results. Results presented in Table 4 indicate that the significance is 0.000 , which is less than 0.05 , so it can be concluded that the model with the previously listed set of independent variables predicts better than the results given in Block 0 . Also, the results presented in Table 5 support the claim that the model is good. Hosmer and Lemeshow Test ( $\mathrm{HL}$ test) is interpreted differently in relation to the previous one, and indicator of poor predictions with this test is the significance less than 0.05 . Small values with large $\mathrm{p}$-values indicate a good fit to the data. In this study, the chi-square for the HL Test is 2.040 , with significance of 0.980 , which is greater than 0.05 , so it can be concluded that this test supports the model. Conclusion on the basis on HL test is that the model is acceptable. The $\mathrm{HL}$ test is not ideal approach to evaluating model fit by computing a goodness-of-fit statistic, but still it is very widely spread in the literature. Alternative models to test the goodness-of-fit of logistic regression models are: standardized Pearson, unweighted sum of squared residuals, Stukel's test, and the information matrix test.

Table 6

\section{Model Summary}

\begin{tabular}{|c|c|c|c|c|}
\hline \multicolumn{2}{|c|}{9.5} & & Cox \& Snell R & Nagelkerke R \\
\hline Step & \multicolumn{2}{|c|}{-2 Log likelihood } & Square & Square. \\
\hline \multicolumn{2}{|c|}{1} & $90.796 a$ & .208 & .578 \\
\hline
\end{tabular}

a. Estimation terminated at iteration number 16 because parameter estimates changed by less than .001.

Cox \& Snell's R Squared and Nagelkerke's R Squared values show how much of the variance of the dependent variable is explained by the model. These indicators represent the pseudo indicators of value $r^{2}$. The values of these parameters are 0.208 and 0.578 , which means that a given set of variables explains approximately between 20.8 and 57.8 percent of the variance, respectively (Table 6). The above approach to calculate R-squared with logistic regression is only one of several different approaches. It seems that in literature does not exist agreement on which approach is best. Solution could be to use these without considering them to be definitive values for the percentage of variance accounted for and to make some reference to their "approximate" accuracy. Table 7 presents indicators that show exactly how well the model predicts the category of liquid/illiquid companies, for each tested case.

Table 7

Classification Table

\begin{tabular}{|c|c|c|c|c|}
\hline \multirow{2}{*}{\multicolumn{2}{|c|}{ Observed }} & \multicolumn{2}{|c|}{ Prediction of liquidity } & \multirow[t]{2}{*}{$\%$} \\
\hline & & 0 Liquid & 1 Illiquid & \\
\hline \multirow[t]{2}{*}{ Liquidity } & 0 liquid & 398 & 3 & 99.3 \\
\hline & 1 Illiquid & 14 & 11 & 44.0 \\
\hline \multicolumn{2}{|c|}{ Overall Percentage } & & & 96.0 \\
\hline
\end{tabular}


Financial Indicators as Predictors of Illiquidity

The values in Table 7 are compared with the values given in Table 3, to determine whether there has been an improvement due to the inclusion of predictor variables. Model with predictor variables successfully classifies $96 \%$ of all cases, which is better than $94.1 \%$ (Table 3). The data in Table 7 indicates that the model correctly classifies $44 \%$ of illiquid companies. Specificity of the model is the percentage share of the group that does not have the tested feature, which the model correctly identified, and which, in our study, is $99.3 \%$ (companies that do not have a problem with illiquidity, for which the model correctly predicts that they do not have these problems). Also, in order to determine the validity of the model, it is necessary to calculate the positive predictive value that represents the percentage share of cases that the model classifies as having the tested features, and that is really observed in this group. The positive predictive value in the model is $78.57 \%$ (positive predictive value is calculated as follows: $\left.11 /(11+3)^{*} 100\right)$, which shows that our model accurately classifies $78.57 \%$ of companies as illiquid. Negative predictive value is the percentage share of cases that the model classifies as the ones with no feature, and that it actually observes in this group, and, in our model, it is $96.60 \%$ (negative predictive value is calculated as follows: $\left.398 /(398+14)^{*} 100\right)$. Table 8 shows data on the contribution of each predictor variable.

To determine which predictor variables contribute significantly to the predictive capabilities of the model, the values given in column Sig are observed. All variables whose value in column Sig. is less than 0.05 represent variables that contribute significantly to predictive capabilities of the model. In our study, eight variables have a significance of less than 0.05 (ATR $p=0.012$; ITR $p=0.019$; FAT $p=0.009$; RACR $p$ $=0.009 ; \mathrm{PM} p=0.029 ;$ ROA $p=0.038$, ROE $\mathrm{P}=0.039$, and EMBA $p=0.015$ ). Accordingly, financial indicators based on which one can predict the short-term illiquidity in companies are ATR, IT, FAT, RACR, PM, ROA, ROE, and EMBA. On the basis of the foregoing, the equations for calculation of the probability that the company is going to be illiquidity is:

$$
p=\frac{e^{9.084+0.063 A T R-0.250 I T-0.173 F A T-4.394 R A C R+0.093 P M-0.088 R O A-0.008 R O E+6.934 E M B A}}{1+e^{9.084+0.063 A T R-0.250 I T-0.173 F A T-4.394 R A C R+0.093 P M-0.088 R O A-0.008 R O E+6.934 E M B A}}
$$

The coefficients $B$ in the second column are placed in the equation to calculate the probability that the analyzed case falls into a particular category. Positive and negative values of the coefficient $B$ indicate the direction of the correlation, i.e. a negative value of the coefficient $B$ shows that increase in the value of the independent variable has the effect of reducing the probability that the company will be illiquid in the future.

Variables in the Equation

\begin{tabular}{|c|c|c|c|c|c|c|c|c|c|}
\hline \multicolumn{2}{|c|}{} & B & S.E. & Wald & df & Sig. & Exp(B) & \multicolumn{2}{|c|}{$95 \%$ C.I.for EXP(B) } \\
\cline { 4 - 10 } \multicolumn{2}{|c|}{ Step 1 } & & & & & & & Lower & Upper \\
\cline { 2 - 10 } & CR & .479 & .470 & 1.038 & 1 & .308 & 1.615 & .642 & 4.060 \\
\cline { 2 - 10 } & Cash & -3.496 & 5.216 & .449 & 1 & .503 & .030 & .000 & 835.102 \\
\cline { 2 - 9 } & FSR & -.060 & .053 & 1.306 & 1 & .253 & .941 & .849 & 1.044 \\
\cline { 2 - 9 } & NWC & .000 & .000 & .893 & 1 & .345 & 1.000 & 1.000 & 1.000 \\
\cline { 2 - 9 } & ATR & .063 & .025 & 6.324 & 1 & .012 & 1.065 & 1.014 & 1.119 \\
\hline
\end{tabular}




\begin{tabular}{|c|c|c|c|c|c|c|c|c|}
\hline & B & S.E. & Wald & df & Sig. & Exp(B) & \multicolumn{2}{|c|}{$95 \%$ C.I.for EXP(B) } \\
\cline { 8 - 10 } & & & & & & & Lower & Upper \\
\hline IT & -.250 & .106 & 5.514 & 1 & .019 & .779 & .632 & .960 \\
\hline DSI & -.001 & .004 & .033 & 1 & .855 & .999 & .991 & 1.007 \\
\hline FAT & -.173 & .066 & 6.895 & 1 & .009 & .841 & .739 & .957 \\
\hline TOAT & -1.099 & .984 & 1.247 & 1 & .264 & .333 & .048 & 2.293 \\
\hline NWCT & .000 & .000 & 2.220 & 1 & .136 & 1.000 & .999 & 1.000 \\
\hline WCT & .679 & .689 & .972 & 1 & .324 & 1.972 & .511 & 7.604 \\
\hline RT & -.165 & .108 & 2.324 & 1 & .127 & .848 & .686 & 1.048 \\
\hline DSR & -.006 & .005 & 1.154 & 1 & .283 & .994 & .984 & 1.005 \\
\hline EFA & .121 & .244 & .246 & 1 & .620 & 1.129 & .700 & 1.821 \\
\hline RACR & -4.934 & 1.882 & 6.874 & 1 & .009 & .007 & .000 & .288 \\
\hline WCCRNWC & .718 & .722 & .991 & 1 & .320 & 2.051 & .498 & 8.441 \\
\hline DER & -.003 & .010 & .091 & 1 & .763 & .997 & .978 & 1.016 \\
\hline PM & .093 & .042 & 4.784 & 1 & .029 & 1.097 & 1.010 & 1.192 \\
\hline ROA & -.088 & .043 & 4.319 & 1 & .038 & .915 & .842 & .995 \\
\hline ROE & -.008 & .004 & 4.258 & 1 & .039 & .992 & .985 & 1.000 \\
\hline ETA & 13.231 & 7.550 & 3.071 & 1 & .080 & .000 & .000 & 4.787 \\
\hline EMBA & 6.934 & 2.837 & 5.974 & 1 & .015 & $1,027.067$ & 3.950 & $267,072.827$ \\
\hline EEA & .108 & .078 & 1.941 & 1 & .164 & 1.114 & .957 & 1.297 \\
\hline Constant & 9.084 & 7.817 & 1.351 & 1 & .245 & $8,817.422$ & & \\
\hline
\end{tabular}

a. Variable(s) entered on step 1: CR, Cash, FSR, NWC, ATR, IT, DSI, FAT, TOAT, NWCT, WCT, $R T, D S R, E F A, R A C R, W C C R N W C, D E R, P M, R O A, R O E, E T A, E M B A, E E A$.

The following independent variables have the negative coefficient: IT $(-0,250)$, FAT ($0.173)$, RACR (-4.934), ROA (-0.088), and ROE (-0.008). The above coefficients indicate that the higher the value of these coefficients, the less likely it is that the company will be illiquid in the future. On the other hand, the coefficients $B$ are positive for the independent variables ATR $(0,063)$, PM $(0,093)$, and EMBA (6.934), indicating that the increase in the values of these coefficients increases probability that companies will have illiquidity problem in the future. The model was tested in the test sample. The accuracy of the model specified in the study is $99.4 \%$ for liquid and $44 \%$ for illiquid companies, i.e. the model correctly classifies $95.3 \%$ of all cases. Obtained predictor variables IT (-0.250), FAT (-0.173), RACR (-4.934), ROA (-0.088), and ROE $(-0.008)$ are in accordance with expectations and theoretical studies published in the Republic of Serbia (Stančić, 2000; Ranković, 2011; Malinić, 2013). However, additional explanations are necessary for positive coefficients for the independent variables ATR (0.063), PM (0.093), and EMBA (6.934).

The explanation for this unusual situation can be found in the following facts:

- Continuous accumulation of losses, which, at the end of 2012, recorded an increase of $8.3 \%$, leads to a distortion of the financial structure, which is manifested through the reduction of equity and a reduction in net working capital, which suggests that although ATR increases (because the denominator of a fraction decreases average equity), company is facing illiquidity, because equity melts faster than revenues from sales decrease;

- Management of the company seeks, by using creative accounting techniques, to reduce the company's income, which can justify the result obtained in our study, 
Financial Indicators as Predictors of Illiquidity

based on which the increase of PM increases likelihood that the company will have illiquidity problem, and

- Operating with the loss in 2012 mainly resulted from a considerable increase in financial loss due to considerably increased interest expense and foreign exchange losses. Positive results of business activities were threaten by the larger increase in financial expenses than financial income, so that, even though the companies recorded growth in respect of the indicator EMBA, its positive effects were neutralized by financial loss which recorded growth in 2012 of $77.5 \%$ (www.apr.gov.rs), so that this fact can justify the view that with the growth of EMBA, the probability of illiquidity increases. Since EFA indicator was excluded from the research, because of multicollinearity, its effect was not analyzed in this paper.

The column showing the values of Exp (B) shows the likelihood ratio for each independent variable. In our study, EMBA has the highest value $(1,027.067)$, followed by PM (1.097), and ATR (1.065). The value of the likelihood ratio for independent variables whose coefficient $B$ has a negative value is less than 1 , and amounts to (0.779) for IT, (0.841) for FAT, (0.007) for RACR, (0.915) for ROA, and (0.992) for ROE. Based on the interpretation of the above values, it could be concluded, for example, that increase in the value of IT reduces the likelihood that the company will be illiquid by 0.779 , when all other factors are equal. In the same way, could be interpreted all specified likelihood ratio values for independent variables whose coefficient $B$ has a negative value, and vice versa, if the coefficient $B$ has a positive value.

For every likelihood ratio in column Exp (B), the corresponding 95\% confidence interval is shown, which indicates the range which can be, with $95 \%$ of confidence, claimed to include the actual value of likelihood ratio. The number listed as the likelihood ratio is the estimate of the actual value, based on data from a sample (confidence we have in the claim that this is the exact value changes with the change of the sample size). If the confidence interval does not include the number 1 , it is considered that the result is statistically significant at $p<0.05$. In our study, the coefficient ROE contains the number 1 , and its likelihood ratio is not statistically significant because we cannot exclude the possibility that the actual likelihood ratio is 1 , which indicates an equal likelihood that the company is liquid, i.e. illiquid.

Logistic regression conducted in this study showed that the following financial ratios can be used as predictors of illiquidity of the company in the coming period: ATR, IT, FAT, RACR, PM, ROA, ROE, and EMBA. The whole model (with all predictors) is statistically significant, $X 2(23, N=426)=99.485, p<0.001$, indicating that the model distinguishes between liquid and illiquid companies. The model, as a whole, explains $20.8 \%$ (Cox \& Snell's R Squared) and $57.8 \%$ (Nagelkerke's R Squared) of variance, and accurately classifies $96 \%$ of cases. The strongest predictor of situation that the company has a problem with illiquidity exists with the indicator EMBA $(1,027.067)$, followed by PM and ATR. The results indicate that with the increase in value of these indicators, the likelihood that the company will be illiquid increases. On the other hand, the growth of indicators IT, FAT, RACR, ROA, and ROE decreases the likelihood that the company will be illiquid in the future. Based on the presented results, it can be concluded that the hypothesis set in this research has been confirmed, i.e. based on financial indicators of the company, short-term illiquidity can be predicted. 


\section{Conclusions}

During the last decades several models to predict the illiquidity and insolvency of the company have been developed. However, given that there is no universal model on the basis of which illiquidity or insolvency can be predicted, the researchers use the data from previous research in order to develop as accurate a model that will be applicable in the circumstances that exist in a particular country. Relying on the results of previous research, our paper is focused on creating a statistical model by applying logistic regression, which, as a result, points to the likelihood that the company will, in the oneyear period that follows, be illiquid. The variables on the basis of which the model is created are financial ratios calculated on the basis of data from financial statements.

Our results show that the financial indicators based on which it is possible to predict the short-term illiquidity in companies are Asset turnover ratio, Inventory turnover ratio, Fixed-asset turnover, Real asset coverage ratio, Profit margin, Return on assets, Return on equity, Effectiveness of main business activity. The results indicate that an increase in the value of inventory turnover ratio, fixed-asset turnover ratio, real asset coverage ratio, return on total assets, and return on equity reduces the likelihood that the company will be illiquid.

On the other hand, it is particularly interesting that the resulting model in the study suggests that an increase in the capital turnover ratio, net profit ratio, and effectiveness of main business activity increases the likelihood that the company will be illiquid. The explanation for these results, perhaps, could be looked for in the fact that the accumulation of losses in large companies in Serbia leads to a distortion of the financial structure, which is manifested through the reduction of equity. What is more, companies tend to use creative accounting technique to reduce profits, and there is also the fact that although large companies realize profit from operating activities, their performance at the aggregate level is mainly dictated by the results achieved on the basis of financial and other activities.

The accuracy of the model specified in the study is $96 \%$, i.e. the model correctly classifies $96 \%$ of cases. The presented model indicates that through the assessment of the current situation, the future financial problems of the company can be predicted.

The model was tested in the test sample. The accuracy of the model specified in the study is $99.4 \%$ for liquid and $44 \%$ for illiquid companies, i.e. the model correctly classifies $95.3 \%$ of all cases.

Hence, we can conclude that management has enough time to take appropriate steps and make decisions to cope with illiquidity problems. In the short term, a good measure is to ensure strict financial discipline and increase efficiency in the management of cash flows. Establishing strict financial discipline is one of the key prerequisites for improving liquidity. Also, it is necessary to prevent misuse of smaller suppliers by large and powerful companies. A good move is the adoption of the Law on the terms of settlement of financial obligations in commercial transactions. Establishing strict financial discipline favors more efficient management of cash flows. For long-term solution to the problem of illiquidity, it is necessary to improve the competitiveness of companies, increase profitability, and eliminate imbalances in the financial structure. 


\section{Financial Indicators as Predictors of Illiquidity}

Results of our study are similar to results of previous research. In all similar research in region PM and ROA is important predictor of illiquidity. These researches indicated that debt to total asset ratio is important predictor of illiquidity (Mramor and Valentincic, 2003; Šarlija, Penavin and Harc, 2009; Tudor, Popescu, and Andreica, 2015). In our study we calculated some other solvency ratios and the most importan predictor is Real asset coverage ratio. However, the specificity of our results for large companies in Serbia stems from the before mentioned specific business environment. Thus, we can conclude that our results are consistent with the economic theory and the literature review.

Bearing in mind that in Serbia there are only few theoretical studies (Stančić, 2000; Ranković, 2011; Malinić, 2013) on this topic, this study can be describe as one of the pioneer projects. Nevertheless, we would like to point to several limitations of our study. Logistic regression is a statistical technique allowing researchers to create predictive models and it is very useful techniques. But logistic regression is just one of the methodological approaches that were developed for the prediction of illiquidity. Some non-lenear models such as neural networks for example can be used in order to capture the true effect (non-linear and non-monotonic) of financial ratios on illiquidity. The second limitation is how independent variables were selected. Financial ratios, as independent variables, are dominantly selected based on models from previous studies. Therefore, this does not mean that this is the optimal mix of ratios. It is possible that the choice of ratios in our study does not fully reflect all specifics features of sample companies and developing Serbian economies.

Also, there are at least two outstanding issues. The first is "do financial ratios have predictive power" and the second "do the financial ratio can describe a dynamic system of corporate functioning". But, these are the limitations that the most researchers came across. Finally, it is necessary to stress that the potential subjectivity of authros, in the implementation of research is potential limitation factor of any research. Having in mind that sample companies represent almost $50 \%$ of all population of large companies in Serbia, we nevertheless, believe that our study offers useful insight into prediction of illiquidity in developing countries like Serbia. This paper attempts to apply an effective tool to assist in predicting corporate financial distress. More studies are needed to continue this process. In many cases, the prediction accuracy can be improved by inventing a more appropriate set of features to describe the available data.

The limitations presented here are also the areas of possible further research on liquidity prediction. Therefore, there are several directions for future research. Future research, within national borders, should include in addition to large companies, medium-sized and small enterprises and the expansion of research to a larger number of years. Inclusion of data from credit bureaus, as well as macroeconomic indicators, as independent variables can contribute to creation of more precise models.

Increasing ability to predict illiquidity can be based on the application of different forecasting models on the same or larger sample. The sample with a larger number of illiquid companies would also represent improvements. The parallel use of different statistical methodologies could provide comparison of the results obtained and the development of more precise prediction model. Research in the area of the region should go in the direction of developing models for predicting illiquidity for companies in developing countries. 


\section{References}

Altman, E.I., 1968. Financial ratios, Discriminant analysis and the prediction of corporate bankruptcy. The Journal of Finance, 23(4), pp. 589-609.

Altman, E.I., 1993. Corporate Financial Distress and Bankruptcy, 2nd ed., Wiley, New York.

Altman, E.I. Marco, G.F. and Varetto, C., 1994. Corporate distress diagnosis: comparisons using linear discriminant analysis and neural networks (the Italian experience). Journal of Banking and Finance, 18(2), pp. 505-529.

Andreev, Y.A., 2005. Predicting financial distress: A Multinominal Logistic Approach to Spanish firms, Working papers. University of Barcelona, Department of Business Economics.

Appiah, K.O. and Abor, J., 2009. Predicting corporate faliure: some empirical evidence from the UK. Benchmarking: An International Journal, 16(3), pp. 432444.

Barnes, P., 1987. The analysis and use of financial ratios: a review article. Journal of Business Finance \& Accounting, 14(4), pp. 449-461.

Beaver, W., 1966. Financial Ratios as Predictors of Failure. Journal of Accounting Research, 4(3), pp. 71-111.

Blanco-Oliver, Irimia-Dieguez, A., Oliver-Alfonso, M. and Wilson, N., 2015. Improving Bankruptcy Prediction in Micro-Entities by Using Nonlinear Effects and Non-Financial Variables. Czech Journal of Economics and Finance, 65(2), pp. 144-166.

Chatterjee, S. and Hadi, S.A., 2006. Regression Analysis by Example, 4th ed.. John Wiley \& Sons, Inc.

Chung, H.M. and Tam, K.Y., 1993. A Comparative Analysis of Inductive Learning Algorithms. International Journal of Intelligence Systems in Accounting, Finance i Management, 2(1), pp. 3-18.

Crone, S.F. and Finlay, S., 2012. Instance sampling in credit scoring: An empirical study of sample size and balancing. International Journal of Forecasting, 28, pp. 224-238

Crook, J.N., Edelman, D.B. and Thomas, L.C., 2007. Recent developments in consumer credit risk assessment. European Journal of Operational Research, 183(3), pp.1447-1465.

Damodaran, A., 2001. Corporate Finance - Theory and Practice, 2nd ed., John \& Son, Inc.

Diakomihalis, M., 2011. Insolvency Prediction: Evidence from Greek Hotels. $8^{\text {th }}$ International Conference on Enterprise Systems, Accounting and Logistics (8th ICESAL 2011), Thassos Island, Greece, pp. 377-387.

Edminster, R.O., 1972. An empirical test of financial ratio analysis for small business failure predtclion. Journal of Financial and Quantitative Analysis, 7(1), pp. 1477-1493. 
Financial Indicators as Predictors of Illiquidity

Fadel, H. and Parkinson, J., 1978. Liquidity Evaluation by Means of Ratio Analysis. Accounting and Business Research, Spring, pp. 101-107.

Grančey, M., 2013. Comparison of performances of neural networks for prediction of bank failures and machines with support vector: the case of Turkey. Economic Research, 26(4), pp. 105-116.

Hosmer, W.D. and Lemeshow, S., 2000. Applied Logistic Regression, 2nd ed., Wiley Series.

Ingram, R.W. and Copeland R.M. 1984. The Association Between Municipal Accounting Numbers and Credit Risk and Return. Advances in Accounting, Vol. 1, pp. $19-40$.

Lev, B., 1973. Decomposition Measures for Financial Analysis. Financial Management, Spring, pp. 36-63.

Lo, A., 1986. Logit versus Discriminant Analysis: A Specification Test and Application to Corporate Bankrtupcy. Journal of Econometrics, 31, pp. 151-178.

Malinić, D. Milićević, V. and Stefanović, N., 2012. Upravljačko računovodstvo. Beograd: Ekonomski fkultet.

Malinić, D., 2016. Mogućnosti i rizici ocene performansi privrede Srbije na osnovu analize finansijskih izveštaja. In Proceedings: Implikacije finansijskog izveštavanja na ekonomsku aktivnost u Republici Srbiji, Beograd: SRRS, pp. 7-37.

Malinić, D., 2013. Infficiency of Serbian Economy's Operating Performances: Manifestations, Causes and Main Guidelines of Recovery. Ekonomika preduzeća, 61(1-2), pp. 41-62.

Masten, A.B. and Masten, I., 2012. Predicting Bankruptcy With Semi-Parametric, Single-Index Model. Economic Research 25(1), pp. 121-133.

Merwin, C.L., 1942. Financing Small Corporations in Five Manufacturing Industries in 1926-1936. New York: National Bureau of Economic Research.

Mramor, D. and Valentincic, A., 2003. Forecasting the liquidity of very small private companies. Journal of Business Venturing, 18(6), pp. 745-771.

Ohlson, A.J., 1980. Financial Ratios and the Probabilistic Prediction of Bankruptcy. Journal of Accounting Research, 18(1), pp. 109-131.

Ranković, J., 2011. Kako su se promenili rentabilitetni i finansijski položaj u privredi Srbije u 2010. godini? Ekonomika preduzeća, 59 (5-6), pp. 262-265.

Rege, U.P., 1984. Accounting Ratios to Locate Takeover Targets. Journal of Business Finance and Accounting, Autumn, pp. 291-311.

Stančić, P., 2000. Predviđanje tokova gotovine - gotovinski budžet preduzeća. Računovodstvo, 45(3), pp. 15-30.

Šarlija, N. Penavin, S. and Harc, M., 2009. Predviđanje nelikvidnosti preduzeća u Hrvatskoj. Zbornik Ekonomskog fakulteta u Zagrebu, 7(2), pp. 21-36.

Tabachnick, B.G. and Fidell, L.S., 2007. Using multivariate statistics, 5th edn, Boston: Pearson Education. 
Tudor, L. Popescu, M.E. and Andreica, M. 2015. A Decsion Support System to Predict Financial Distress. The case of Romania. Romanian Journal of Economic Forecasting, 18(4), pp. 170-179.

Van Horne, J., 1995. Financial Management and Policy, 10th edn, New Jersey: Prentice Hall International, Inc.

Zhang G. Hu, M. Patuwoa, E. and Indro, D., 1999. Artificial neural networks in Bankruptcy Prediction: General framework and Cross-Validatio Ann alysis. European Journal of Operational Research, 116, pp. 16-32.

Yang, A. R. Platta M. B. and Platt, D., 1999. Probabilistic neural networksin Bankruptcy Prediction. Jouranl of Busines Research, 44, pp. 67-74.

"Official Gazette of RS", Nos. 46/2006, 111/2009, and 99/2011, Item 6, Classification of legal entities, Art. 7

www.apr.gov.rs

www.nbs.rs 
Financial Indicators as Predictors of Illiquidity

\section{Appendix}

\begin{tabular}{|c|}
\hline Ratios of liquidity \\
\hline Current ratio $(\mathrm{CR})=$ working capital $\div$ short-term liabilities \\
\hline Quick ratio $(Q R)=($ working capital - inventories $) \div$ short-term liabilities \\
\hline Cash ratio $($ Cash $)=$ cash $\div$ short-term liabilities \\
\hline Financial stability ratio $(F S R)=$ fixed assets $\div$ (equity + long-term dept $)$ \\
\hline Net working capital $($ NWC) = current assets - current liabilities \\
\hline Ratios of activity (turnover) \\
\hline Asset turnover ratio $(A T R)=$ net sales $\div$ average total assets \\
\hline Inventory turnover $(\mathrm{IT})=$ net sales $\div$ average total inventories \\
\hline Days' sales in inventory (DSI) = 365/IT \\
\hline Fixed-asset turnover $(\mathrm{FAT})=$ net sales $\div$ average total fixed assets \\
\hline Total operating asset turnover $($ TOAT $)=$ net sales $\div$ average total operating assets \\
\hline Net working capital turnover $(\mathrm{NWCT})=$ net sales $\div$ average total net working capital \\
\hline Working capital turnover $(\mathrm{WCT})=$ net sales $\div$ average total working capital \\
\hline Receivables turnover $(\mathrm{RT})=$ net sales $\div$ average total receivables from customers \\
\hline Days' sales in receivables $(D S R)=365 \div R T$ \\
\hline Ratios of solvency \\
\hline Equity to Fixed Assets $(E F A)=$ equity $\div$ fixed assets \\
\hline $\begin{array}{l}\text { Real asset coverage ratio }(\text { RACR })=\text { long-term capital }(\text { Long-term debt }+ \text { Equity }) \div \\
\text { real assets }\end{array}$ \\
\hline Inventory coverage ratio NWC $($ ICRNWC $)=$ NWC $\div$ inventories \\
\hline Working capital coverage ratio NWC $($ WCCRNWC $)=N W C \div$ working capital \\
\hline Debt/equity ratio $(D E R)=$ total dept $\div$ equity \\
\hline Ratios of profitability \\
\hline Operating margin $(\mathrm{OM})=$ operating profit $\div$ net sales $* 100$ \\
\hline Profit margin $(P M)=$ net income $\div$ net sales $* 100$ \\
\hline Return on assets $(R O A)=$ net profit $\div$ average total operating assets \\
\hline Return on equity $(\mathrm{ROE})=$ net profit $\div$ average net equity \\
\hline Ratios of cost effectiveness \\
\hline Effectiveness of total activity $(E T A)=$ total income $\div$ total expenses \\
\hline $\begin{array}{l}\text { Effectiveness of main business activity }(E M B A)=\text { operating income } \div \text { operating } \\
\text { expenses }\end{array}$ \\
\hline $\begin{array}{l}\text { Effectiveness of extraordinary activity }(E E A)=\text { extraordinary income } \div \text { extraordinary } \\
\text { expenses }\end{array}$ \\
\hline Effectiveness of financial activity $(E F A)=$ financial income $\div$ financial expenses \\
\hline
\end{tabular}

